\title{
Avoiding the Pitfall of Progress and Associated Perils of Evolutionary Education
}

\author{
Alexander Werth \\ Published online: 10 May 2012 \\ (C) Springer Science+Business Media, LLC 2012
}

\begin{abstract}
People reflexively see all change as implying inevitably increasing progress and complexity. This expected directionality is especially observed in students' views of living things, with some species envisioned as "higher" or more evolved. Students tend naturally to see all evolutionary change as adaptive, progressive, optimal, and teleological, with improvement achieved as needed or desired by organisms (if not as planned in advance). Following an extended outline of many interrelated ways, this basic yet unfortunately widespread and deep-seated misconception of evolutionary thinking ensnares students and hinders proper understanding of the actual pattern and process of evolution, a more useful pedagogical approach is presented. A strategy that involves eliciting preconceptions, engaging in numerous counterexamples, and continually reinforcing an alternative view is generally effective. This is best achieved by tackling the misconception of progress head-on, with an active learning model that forces students to come up with substitute explanations. Several examples of exercises and activities to combat the universal and automatically intuitive inclination toward teleological notions of progress are given, including analyses of paleontology, ecology, biochemistry, development, and systematics.
\end{abstract}

Keywords Teaching evolution - Misconceptions ·

Progress $\cdot$ Directionality $\cdot$ Complexity $\cdot$ Teleology

\section{Introduction}

"Progress! Progress!" shouts Arthur Brooke, a character in George Eliot's novel Middlemarch, published the same year

\footnotetext{
A. Werth $(\bowtie)$

Department of Biology, Hampden-Sydney College,

Hampden-Sydney, VA 23943, USA

e-mail: awerth@hsc.edu
}

(1871) as Charles Darwin's Descent of Man. Indeed, progress was the watchword of Victorian (Darwinian?) times, as change swept through England. Thus, it is not surprising that Darwin's contemporaries accepted his "one long argument" in favor of evolutionary change more readily than they did his truly groundbreaking development (with Alfred Russel Wallace) of natural selection, which was a simple but bold new idea, whereas the concept of the mutability of species long predated Charles Darwin, having been speculated upon by many predecessors including his grandfather Erasmus Darwin. Part of the explanation for this disconnect stems from the fact that people are inherently teleological creatures (Kelemen and Rosset 2009) who have a difficult time accepting change when it relates to the philosophical materialism offered by Darwin-with its unsettling consequences for our place in the vast universe- yet who readily accept change as an unfolding of some master plan. Divine or not, we have a tendency, like Mr. Brooke's character, to view all change as progressive (Blitz 1992; Ruse 1997; Carroll 2001; Gregory 2009b). Like it or not, we are seduced by Aristotle's scala naturae (Great Chain of Being), and therein lies a potential pitfall for biology students and educators.

I was reminded of this recently while explaining different animal excretory systems to college freshmen. After describing to my class the simple flame cells and protonephridia of flatworms, then the segmental metanephridia of earthworms, I had to check myself before stating that "the next step" in evolution is the appearance of the vertebrate nephron. Surely no students would have cared, let alone noticed, had I presented various morphological forms with these words. Indeed, had I not paused and made an extra effort to explain to my class why such a step-wise parade of progress is a misguided view, students would undoubtedly have developed just such a notion of excretory systems with no help from me (in no small part because of the conscious or subconscious order in which I 
presented them). This is a natural, intuitive inclination for everyone (Kelemen 2003), and it is precisely why teachers of evolutionary concepts must check, as best they can, hardwired prejudices at the door. We must choose the words we use carefully, but it is not enough merely to replace the terms "primitive" and "derived" with plesiomorphic and apomorphic - these tongue-twisting words, though proper, frequently confuse, and the original prejudice often goes uncorrected.

The chief problem is that we need to learn lessons of evolution by observing nature directly, not through a lens of cultural expectations. Because principles of evolution and organismal design often run counter to what upbringing and intuition tell us, teachers must be especially careful to dispel rather than confirm familiar yet faulty myths and misconceptions (Nelson 2008). This paper presents suggestions gleaned from two decades of careful scrutiny while teaching evolutionary biology, and especially from an in-depth, quantitative ten-year longitudinal survey of evolutionary education (using anonymous questionnaires; results reported in Werth 2009) meant to break bad habits and instill good habits in biology educators. The list could be longer, but numerous websites and publications already deal with general misconceptions surrounding evolution. This paper instead focuses particularly on common fallacies associated, erroneously, with misbegotten evolutionary notions of progress, along with detailed suggestions for how to correct such misconceptions and, importantly, how to avoid them in the first place.

\section{A Suite of Misconceptions Relating to the View of Evolution as Progress}

\section{"New and Improved": The Crucial Importance of Unlinking "Different" from "Higher and Lower"}

As with the excretory system example cited above, when I contrast the incompletely divided heart of amphibians and reptiles with the fully divided four-chambered heart of birds and mammals, I am careful not to refer to the former condition as an inferior forerunner of the latter. As I make clear, frogs are perfectly happy being frogs, thank youthey are not trying to ascend an evolutionary ladder on a trek toward humanity (Mead 2009). Amphibians and reptiles have been successful on their own as measured by diversity, abundance, and evolutionary time span. If they were not, they would not have survived.

Indeed, the incomplete division of the ventricle can be seen as a useful adaptation given that many amphibians and reptiles undergo prolonged periods of apnea (breath-holding), in which a circulatory shunt bypassing the lungs and diverting blood instead to the systemic circulation is highly effective (Hill et al. 2008). The more active endothermic birds and mammals, with their high metabolic rates, have no use for such an adaptation. In other words, the incompletely divided heart can, and probably should, be seen as advantageous rather than limiting. To amphibians and reptiles, it is a benefit, not a drawback. Why is it seldom presented this way? It is because the notion of inevitably increasing progress (Ruse 1997; Carroll 2001) is a difficult snare to avoid, even for trained biologists. When viewed from the human perspective, it is easy to fall into the trap of equating "different" with "inferior." No less an authority than Darwin himself admonished, "Never use the words higher and lower" (Desmond and Moore 1994). We expect that all change is for the better and that any derived taxon or condition is not only new but "improved" from the "primitive" (ancestral) condition. Natural selection produces highly complex structures (Petto and Mead 2008), but evolution sometimes leads to less complexity (e.g., mammalian skulls have fewer bony elements and moving parts than the reptilian skulls they evolved from). As with the cases of excretory systems and hearts, different does not imply better or worse. Consider, as another example, the fact that humans, like other vertebrates, raise cardiac output by increasing heart rate, whereas invertebrates tend to boost cardiac output by increasing stroke volume instead. Both solutions achieve the desired outcome, though in entirely different ways. Can we say that one solution is better?

Living Fossils and Dead Fossils: Does Paleontology Support the Notion of Increasing Complexity?

McShea (1991, 1996, 2001) claims that, although the idea of rising complexity throughout evolutionary history is widespread and deeply entrenched, the empirical evidence for this claim is spotty and depends on the eye of the beholder (Gregory 2008a; Petto and Mead 2008). For example, the evolution of some segmented animal phyla involved an apparent loss or fusion of various body segments into a smaller number of simpler and stronger if more diverse segments. An example repeatedly cited by McShea (1991, 1993) involves the evolution of the vertebrate spine: A survey of mammalian lineages shows an equal number of increases and decreases in complexity. The origin of the tetrapod vertebral column (holospondylous and monospondylous, meaning with a single fused centrum per body segment) from that of ancestral fishes likewise demonstrates a marked decrease in vertebral complexity. With a little effort, one can easily think of other examples where organisms have evolved to be less complex, such as endoparasites losing organ systems, avian lineages leading to flightless species, or snakes, whales, and other tetrapods losing limbs. In the case of aquatic ancestors leading to terrestrial descendants that later returned to the sea, this involved an abrupt about-face or reversal of "progress." 
Counterintuitively, "higher" organisms do not necessarily have larger genomes than "lower" taxa. Humans have fewer genes than many plant species and fewer base pairs than many plants, invertebrates, fishes, amphibians, and protists (Raven et al. 2007). A decade ago, biologists presumed that the human genome included perhaps a quarter of a million genes, but the current best estimate involves a tenfold decrease (to 25,000 or so), though we now understand that with alternative gene splicing, a smaller number of genes can produce large numbers of polypeptides and highly complex phenotypes.

Still, McShea and Brandon argue (2010) that "in any evolutionary system where there is variation and heredity, there is, in the absence of constraint, a tendency for diversity and complexity to increase." Such constraints may be intrinsic (e.g., genetic) or extrinsic (environmental), and this may be why some "living fossils," including horseshoe crabs and horsetail (Equisetum) plants, have scarcely changed if at all over hundreds of millions of years. Countless other examples of apparent evolutionary stasis (at least in morphology) can be cited, ranging from brachiopods, lungfish, lampreys, coelacanths, and the chambered nautilus to lycopods, cycads, tree ferns, and other plants including the ginkgo, dawn redwood, and Wollemi pine. It is useful to remind students of Van Valen's "Red Queen" hypothesis (1973), which holds that - like the Queen of Hearts in Alice in Wonderland, who claimed that "It takes all the running you can do, to keep in the same place"-organisms exist in complex ecological webs and often evolve mainly to keep up with constant changes in the biotic or abiotic parts of their ecosystems. It may well be that "living fossils" have evolved greatly in biochemistry, physiology, or behavior (or just in non-coding DNA, with the ceaseless ticking of the molecular clock), even if such changes are not apparent in divergence of form from specimens in the fossil record.

\section{King of the Hill: Can Some Species be "More Evolved"?}

Students often speak of species that are "more evolved." It is hard to know exactly what this means. Are not all extant organisms equally evolved? My guess is that even while accepting biological evolution, people cannot break free from the tyranny of Aristotle's "Great Chain of Being," with humans enthroned as "King of the Hill." We forget that, since the lineages of amphibians and amniotes diverged, both groups have had the same time period over which to change. In other words, they are equally distant from their most recent common ancestor. As Dawkins (2004) warns, we must be cautious when we say, for instance, that onychophoran velvet worms (Peripatus) "bridge the gap" between annelids and arthropods. What gap? If we think of evolution in terms of a progressive chain or ladder, it is easy to envision missing links or steps. But this is surely an unrealistic view (Schwenk 2002). We imagine all fossil forms as ancestors on a direct, progressive path. We forget that The Origin of Species has but one diagram, signifying evolutionary relationships: not a ladder or chain, but a bush. In this regard, it is instructive to ask students to explain in what ways Homo sapiens is more evolved than Escherichia coli. Yes, bacteria more closely resemble the last universal common ancestor, but does this mean they have stopped evolving?

Don't Adaptive “Arms Races" Mean that Evolutionary Change Always Reflects "Improvement"?

This is not to imply that the issue of progress in evolution is simple. Although Stephen Jay Gould (1989) vehemently cautioned against equating change with progress, Darwin's bulldog himself (Thomas Henry Huxley) and his grandson Julian Huxley both argued that evolutionary advances could be considered tantamount to progress (Desmond 1997). A book by philosopher Michael Ruse (1997) is subtitled "The Concept of Progress in Evolutionary Biology," attesting to the prevalence of such arguments and predominance of this view. One cannot deny that strong selective pressures push gene pools (as in directional selection) quite steadily, often in a ratcheting process, or that coevolutionary arms races lead to spiraling increases in adaptations. Adapting to different peaks on an adaptive landscape can lead to some evolutionary outcomes being more likely than others, as in convergent evolution. However, we must be careful not to equate newer with better, and we must be especially vigilant in not confirming students' default expectations that evolutionary change is a fulfillment of some grand plan. Alas, the very word "evolution" itself refers to unrolling or unfolding, as of a previously penned script. We must make clear that evolution operates in the present, without looking ahead or planning for a preordained future.

Function vs. Purpose: The Pervasive Peril of Teleological Thinking

The seductive siren of teleology has long been recognized (Ayala 1970; Jungwirth 1975; Bartov 1978; Lennox 1993; Dawkins 1995; Williams 1998; Ruse 2000b; Zohar and Ginossar 1998; Zeigler 2008; González Galli and Meinardi 2010; Mead and Scott 2010a, b), but recent studies (Kelemen and Rosset 2009) reveal just how automatic and deep-seated our tendency is to explain natural phenomena in terms of purpose and how this contributes to our view of evolution as progressive (Quammen 2006). We are intentional creatures; we see intention everywhere (Kelemen 2003). Although research reveals that this inclination is independent of religious proclivity (Kelemen 2004a, b), the propensity for teleology provides natural support to creationist tendencies (Atran 1998; Kelemen 1999; Kelemen and Rosset 2009), making the job of biology teachers all the more difficult (and imperative). Paley's 
argument from design remains a major obstacle to evolutionary thinking (Gregory 2009a; Mead and Scott 2010a). As Gregory (2009b) warns, teleological explanations are so deeply ingrained that even biologists say such things as "fungi grow in forests to help decomposition" or "finches diversified in order to survive" (Kelemen and Rosset 2009).

When I explain to students that, strictly speaking, a heart or wing has no purpose, they invariably look at me cross-eyed. When I go on to explain that these structures indeed have functions, but that the word "purpose" implies, as in Aristotle's telos (final cause), a foreseen goal or end point, they finally see the crucial distinction, which is that other, equally effective solutions could have evolved to pump blood or generate lift forces for flight. The difference in semantics may be negligible, but in viewpoint it is great.

Wings and Flippers: Doesn't Convergence Indicate Evolutionary Progress?

The fact that many similar features appear throughout evolution gives the impression of inexorable evolutionary progress. Does not the way that marine mammals (cetaceans, sirenians, pinnipeds) have independently evolved flippers lend credence to the notion that common solutions are inevitable? Kelly (2010) argues that the repeated evolution of such traits as flapping flight, echolocation, camera-like eyes, brains, and even intelligence was not accidental but represents an inevitable outcome. Conway Morris (2003) further argues that catastrophic events such as asteroid impacts or other major extinction events can delay evolutionary events but ultimately affect only the timing, not the eventual, inexorable result. In fact, the observation that similar features arise again and again via convergent evolution does not indicate progress per se, especially when one focuses on homology rather than analogy-look at all the different types of analogous wings and other flying or gliding membranes. Convergence, yes; progressive advancement, no. Bird and bat wings are homologous as vertebrate forelimbs but analogous as wings, for their common ancestor possessed a limb with a radius, humerus, and ulna, but not in a wing form. If all evolutionary roads led to the same destination, this might be construed as evidence for progress, but in fact these roads are at best merely parallel. What might appear from a distance to be a single type of wing turns out upon closer reflection to be several types, each reflecting disparate origins and contrasting ontogenetic/phylogenetic pathways as much as or more than ultimate end points.

Culmination vs. Contingency: How Important

Are Stochastic Events in Evolution?

Gould's Wonderful Life (1989) notion of rewinding and replaying the tape of history, leading to an entirely different present day due to all sorts of chance historical contingencies, provides a valuable starting point for classroom discussions of evolutionary progress and directionality. In Gould's words (1989), "Life is a copiously branching bush, continually pruned by the grim reaper of evolution, not a ladder of predictable progress." Yet Conway Morris (2003) argues, contra Gould, that, if the tape of evolution were to be replayed, humans or at least some intelligent biped would in fact be the inescapable end product. Dawkins accepts the role of contingency but argues $(1996,2003,2004)$ likewise that evolution is rife with predictably recurring patterns, such as the repeated independent evolution of eyes, electric organs, and so on, and offers as explanation a combination of convergence with constraints, with different lineages facing similar selection pressures and responding with limited solutions. Dawkins (2004) further suggests that watershed events in evolutionary history, including origins of eukaryotic cells, multicellularity, and sexual reproduction, presented major steps in "evolvability" (Wagner 2007), providing raw materials that paved the way for more advanced organisms. Dawkins (2004) is quick to qualify his hesitating support for "progressive evolution" by referring to a "value-free" rather than "value-laden" progress in which change occurs in a direction one might consider desirable - according to some normative value system, as toward humanity (if we are to be considered the pinnacle of life) - which seems reasonable, from our anthropocentric perspective.

\section{Does Natural Selection Lead to Progressively}

More Adaptive Design?

Arms races, convergence, and constraints on organismal form and function together give at least the appearance of design, which is often taken by those with a limited understanding of evolutionary mechanisms to mean some sort of preordained, intelligently fostered design. In response, Shermer (2006) baldly states that we should "quit tiptoeing around" and admit that design appears in nature, though solely from a step-wise, bottom-up mechanism-what Dennett (1995) refers to as cranes rather than (top-down or divine) skyhooks. Dawkins (1996) introduced the term "designoid" to signify evolutionary design: not designed in an intentional, purposeful sense, but in a non-teleological, evolutionary sense (as with the purpose vs. function heart example). The bottom line is that adaptive evolution might be considered progressive in the sense that it involves a cumulative, ratcheting process, but not in the sense of moving toward a planned outcome or goal (Aristotle's telos; Williams 1998; Ruse 2000b; Weber 2011). Nonetheless, some continue to argue (e.g., Wright 2001) that life, and humanity in particular, inevitably progresses in this ratcheting fashion due to the steady accumulation of ordered, directed change. 
Do Thermodynamics and Energy Flow Lead to Inevitable Evolutionary Progress?

Although evolutionary biologists recognize that life has, since its origins, increased in size and diversity, they do not necessarily accept this as inherently progressive (Chorost 2012). Carroll (2001) argues that because we fixate on complex organisms, the appearance of progress as a necessary "forward march" is illusory. When there is nowhere to go but up, some species will go up. Other scientists (Rubi 2008; Smart 2009; Chaisson 2011) argue that evolution is invariably driven toward progress by certain inescapable processes, among them basic laws of physics. Rubi (2008) claims that order emerges from chaos where there is excess energy - as with Earth's open system with regard to the sun's energy (thus countering the inevitable increase in entropy from the second law of thermodynamics) - and therefore complexity arises in living systems because of this favorable energy gradient. Chaisson (2011) argues that energy rate density, a measure of how much energy flows through each gram of a system per second (Chorost 2012), is a universal gauge to quantify the complexity of ordered systems. Analysis of energy rate density, he contends, reveals an unequivocal upward trend in complexity concomitant with the "ascension" of life from microbes to humans and from hunter-gatherers to technological societies. Yet, although we share the planet with many complex organisms, we also witness organisms (including many parasites) that achieve success due to simplicity. Complexity may be a trend, but it is not an inevitability. Naturalistic explanations can be offered for life's diversity, but they need not imply a forward or upward march.

\section{Just So Stories: Does All Evolution Involve Adaptive Change?}

A similar (and similarly big) pitfall for evolutionary educators, related to this problem of directional progress, involves presenting each feature of an organism as an adaptation. This is the unfortunately rife "adaptationist program" criticized by Lewontin and Gould's "Spandrels of San Marco" paper (1979). Much writing about organisms, not only in texts and secondary literature but in original research papers, holds fast to this paradigm, presenting "just so" stories (ad hoc fallacies) that are in some cases a short step from Kipling's amusing tales (1902) about how the leopard got its spots or the elephant its trunk. Examples are plentiful in human biology, including the "aquatic ape hypothesis" (hairless humans must have evolved from early hominins that lived in the sea) and ideas about why humans are good runners or why we hold religious beliefs, or about human form, diet, and behavior (Schlinger 1996; Allcock 2001). Darwin's well-known contemplation (1859) that a bear feeding open-mouthed in a river was potentially on the road to becoming something like a whale could be cited as a just so story - an untested and untestable idea that makes sense and could be true - but examples can be found in modern biology, such as Barash's analysis of bluebird mating behavior (1976), which Gould (1978) criticized as storytelling.

Educators must make clear that traits may be ecologically "indifferent" (neither beneficial nor harmful) or may "come along for the ride" due to epistasis or genetic linkage. A clear example of linkage involves the wild silver foxes (bred by Soviet biologist Dmitri Belyaev for tameness) which ended up looking much like domesticated dogs with curled tails and floppy ears (Trut 1999). It is possible that traits may have been adaptive at some point but no longer are today. Still other features, like the long, gaudy tails of peacocks, may be advantageous via sexual selection yet maladaptive in the broader arena of natural selection. It is essential for students to learn that selection is not the only agent of evolutionary change, that not all traits are adaptive, and that adaptations are context-dependent. Evolution occurs from genetic drift and gene flow, with migration of individuals into and out of populations, and hence of alleles into and out of gene pools. Mating is often non-random, and of course, many neutral and silent mutations occur at random. Inherited traits are often linked to other traits.

New discoveries in evolutionary developmental biology (evo-devo) have led to great strides in evolutionary thinking, with biologists (Gould 2002; Carroll 2006; Kirschner and Gerhart 2005) explaining the role of "facilitated variation" and the importance of regulatory genes in the origin of key innovations. Kirschner and Gerhart (2005) argue that the "irreducible complexity" argument prominently espoused by intelligent design creationists (Forrest 2008; Shanks and Green 2011) is largely undone by advances in evo-devo, which suggests ways complex organs, such as vertebrate limbs (or the eye that bedeviled Darwin; Buschbeck and Friedrich 2008; Gregory 2008b), may undergo major transformations not from gradual ("progressive") accumulation of minor mutations in structural genes but instead from minor tweaking of regulatory (e.g., homeobox) genes. Epigenetics is another burgeoning branch of biology that adds richness to the study of phenotype, especially as it suggests ways in which environmental circumstances might lead to genomic imprinting and hence inheritance of traits influenced by long-ago conditions experienced by ancestors (Jirtle and Skinner 2007).

A valuable exposition of this topic, and a cautionary tale about just-so adaptive stories, can be found in Gould's essay "Of kiwi eggs and the Liberty Bell" (1986), explaining how the disproportionately gigantic eggs of kiwi birds make sense not as an adaptation but as a historical holdover from their much larger ancestors. Gould writes: "This assumption- the easy slide from current function to reason for origin - is, to my mind, the most serious and widespread fallacy of my 
profession, for it lies embedded in hundreds of conventional tales about pathways of evolution... When you demonstrate that something works well, you have not solved the problem of how, when, or why it arose." In trying to dispel this Panglossian paradigm, Gould offers a humorous anecdote of his trying to suss out the mythic significance of the words "Pass and Stow" cast onto the Liberty Bell (like the biblical inscription from Leviticus, "Proclaim liberty throughout all the land unto all the inhabitants thereof," which also appears on the bell), only to find that the words referred simply to the names of the two men who cast the iron bell. Gould noted (1986) that we make this "easy slide" because "we want answers that invoke general laws of nature rather than particular contingencies of history" (Gould 1989) which are not nearly as satisfying to us.

\section{Ladder vs. Bush: Does Evolution Proceed} in a Straight Line?

Culmination versus contingency arguments abound in the study of human evolution. These can help students think critically about evolutionary histories depicted as anagenesis or orthogenesis (an inevitable "straight line" of progressive evolution) rather than as chance contingencies, as in Ray Bradbury's short story "The Sound of Thunder" (1952), in which a man who travels backwards in time to view dinosaurs incidentally swats an insect, then returns to the present only to find that everything has changed. Relethford (2005) gives a similarly clever example from an episode of the original Outer Limits TV show entitled "The Sixth Finger," in which a time machine with "backward" and "forward" levers allows a man to travel to the future, where he evolves a sixth finger for extra dexterity. The time machine's "forward" function implies a fixed path for the future, as of the unrolling or unfolding of an already-written scroll. For an alternative view, consider that if our ancestral amphibian had not crawled ashore with a pentadactyl limb, we would have no base-ten (i.e., decimal) mathematics. As Monday morning armchair quarterbacks know, hindsight is 20/20. Postdiction is easy. Prediction is the hard part.

\section{Preadaptation: Planning Ahead?}

Preadaptation is a problematic concept related to prediction. Blessed with the gift of foresight, we tend to imagine the future can always be anticipated and that organisms routinely do so, planning progressively. How else to explain the evolution of complex eyes and wings, and the dreaded problem of irreducible complexity (Gregory 2008b)? Yet we now know that changes in regulatory toolkit genes lead to rapid, major shifts in body plans, just as we understand that the functions of structures can change as surely as their forms. Once again, teachers must nimbly navigate a minefield of counterintuitive notions. Did the dinosaurian ancestors of birds use feathers for courtship displays, thermoregulatory insulation, or traps to capture insects before flight evolved? All of these hypotheses involve preadaptation. Insect wings may have arisen from structures used as heat radiators, which pre-adapted some insects for flight capacity (Kingsolver and Koehl 1985). This leads to interesting questions of evolvability and whether some taxa or biological systems enjoy a greater capacity for adaptive evolution (Wagner 2007). This is a fascinating topic, but, to avoid student confusion, it is often better to answer questions about preadaptation with the related (mostly synonymous yet non-teleological) terms exaptation or co-option (McLennan 2008).

Students easily fall into the trap of believing that current structures reflect a progressive change from initial adaptations: We evolved our upright posture so we could reach up and change light bulbs, or so we could punt, pass, and kick a football. Yes, a shoe can serve as a flyswatter, hammer, weapon, percussion instrument, and so on, but those were not its initial function. Could the absence of a tail in humans and apes be linked to sitting and walking upright? That's an entirely plausible explanation, but that doesn't mean it is the correct one. Perhaps tail loss was genetically linked to a mutation that gave apes greater shoulder flexibility or larger brains. The flip side, of course, is that just because something is unlikely doesn't mean it can't occur. People do win the lottery, even against astonishing odds. Animals do cross oceans on makeshift rafts of palm fronds. Given the extraordinarily vast timescale of evolutionary history, we should not be surprised that unlikely things might occasionally happen.

\section{Aren’t Organisms Optimally Designed?}

Another fallacy relating to progressive notions of evolution holds that organisms are perfectly designed. Numerous examples including the panda's thumb (Gould 1980), male nipples, and countless vestigial organs in humans (Shubin 2008) and other species have yet to dispel this notion. Unfortunately, one might easily presume, given the overwhelming number of species that have gone extinct, that all the extant survivors are success stories that are perfectly adapted to their conditions. A moment's reflection, however, reminds one of the old joke about the two campers attacked by a bear: The one that survived didn't need to outrun the bear, but only had to outrun the fellow camper. In the same way, the "winner" of a genuine competition is better than its competitors, but this does not mean it is perfect or close to it. A winner emerges from every golf or tennis tournament, even if none of the competitors is skilled. Ecological concepts of competitive exclusion tell us that the actual (realized) niche of a species will be constrained by competition and that organisms may be forced into poor 
habitats that would not otherwise be suitable. Plants and animals that live in a harsh desert might "prefer" to live elsewhere but have adapted or otherwise come to live in a place where they can survive the competition.

Students must be reminded that evolution neither crafts perfection nor begins with a fresh blueprint. Form often follows function, but not invariably. Sometimes form follows history, not only in nature but in the human realm as well: The QWERTY keyboard (designed to avoid jammed typebars) is a familiar example, as is the railroad gauge which arose, two millennia later, from the distance between Roman chariot wheels. Other times, neutral form is governed simply by mechanisms of inheritance. We forget that evolution tinkers rather than fashions organisms de novo from a proverbial blank slate. Organisms carry their historical baggage, which explains why humans are prone to bad backs, flat feet, and impacted wisdom teeth, and why we have a vermiform appendix, vestigial ear muscles, and male nipples.

Complexity and Progress: Do All Features of an Organism Evolve at the Same Rate?

A problem that trips up many students is the idea that all features of an organism change at the same rate. This poses a major challenge for thinking about human evolution, as people presume there is a "missing link" somewhere between our own species and our closest living relative that fills a space exactly halfway in between. This claim presumes that all human features (bipedalism, big brain, relative hairlessness, language, and so on) arose at the same time and thus, that there was, at some time, some organism that was "halfway there" along this spectrum. Not only does the fossil record not show any such links (in any lineage), but further reflection reveals that the impression that diverse characteristics of a species appear and evolve at the same rate is unlikely to be supported by paleontology - it is nonsensical.

Instead of this vision of steady evolutionary progress, a more realistic view depicts each species as a mosaic blend of old (primitive) and new (derived) features. As Kardong (2008) points out, the duck-billed platypus, Ornithorhynchus anatinus, is a fine example of this mosaic concept. In form and function alone, there are obvious ways it qualifies as a "primitive mammal" (egg-laying, male mammary glands, weak thermoregulation), but there are just as many other features that make it a highly derived mammal (electroreceptive snout, venom glands). An apparent adverse effect of this view of cumulative, progressive evolutionary change is that students more readily accept evolution of bones and other physical structures rather than of less tangible features like biochemical pathways or behaviors; the latter in particular pose a problem for many people (Werth
2009). In this regard, Dawkins's idea of the extended phenotype (2004) is especially useful: A beaver dam should be considered an expression of beaver genes.

One of the things we must perpetually bear in mind is that most organisms, or parts of organisms, are complex structures. Is your head for feeding, for breathing, or for sensory input and neural processing - or for all of the above? The head is a highly elaborate functional matrix (Lieberman 2011) with many specific functions that fulfill various biological roles. It must likewise be realized, harking back to the fallacy of optimal design, that many features of organisms represent a functional compromise. The head of the human femur breaks off in many elderly women, but then again the pelvis is a compromise "built" to satisfy competing demands: It would presumably be wider if we were not bipedal, but narrower if we had smaller brains. As it is, the pelvis is just wide (or narrow) enough to allow humans to be both big-brained and bipedal, but it occasionally fails us by leading to broken hips or mothers (and babies) who die while giving birth. Kardong (2008) offers another apt example of a functional compromise, showing the wings of plunging seabirds (boobies, gannets, terns, etc.) as intermediate between the long, narrow wings of soaring gulls and albatrosses and the short, wide wings of swimming penguins. Is this progress?

Mutation on Demand and the "Great Warehouse in the Sky": Do Organisms Get What They Need or Want?

Consider the following excerpt from a letter (Popielarz 2003) to a newspaper editor, complaining that an article about evolution in bacteria describes no such thing: "I don't believe the bacteria to which the author is referring are 'evolving' into a more complex form such as a guppy; they are adapting to the anti-bacterial agents being used and becoming immune much as a person becomes immune to various illnesses. A dog living outdoors in a cold environment does not evolve a heavy coat of fur and become a bear. Rather, he adapts to the cold by developing a heavy coat." Surely the letter writer is misinformed about the dog acclimatizing (not adapting) to different seasons, nor does he understand that the bacterial change involves modification from one generation to the next, much as he differs from his parents, and his children, if any, differ from him. Students and others with less background and experience in evolutionary education tend to forget that populations evolve, not individual organisms.

Students also forget just how such changes occur. A fallacy related to progressive "just so stories" involves the mistaken view of mutation on demand. We slide into the trap of thinking organisms choose adaptations they need, or that natural selection simply gives them adaptations. We speciously confuse cause and effect (Mead and Scott 
2010b), as by thinking antibiotics cause bacteria to evolve resistance, rather than that some bacteria randomly possess natural resistance, so that survival of these microbes when coupled with the death of non-resistant bacteria leads to a rapid change that looks for all the world (particularly from our teleological perspective) as if the one event directly brought about the other, though this was not of course caused by but instead was an effect of antibiotic use. Organisms cannot change merely by striving or needing, despite the claims of Teilhard de Chardin and Lamarck. To take the classical evolutionary example, giraffes did not attain their height because of "trying" to get taller.

Teleological thinking is undoubtedly commonplace in biology because we intuitively expect living things (and other apparently animate entities, like storms) to act the way we would, with intentions and desires (Mead and Scott 2010a, b). This is commonly manifested in explanations that consciously or subconsciously suggest that biological phenomena involve molecules or cells acting as if they were invigorated and motivated by tiny minds: Ribosomes and RNA molecules busily put together polypeptides like workers on a construction site; hormones, antibodies, and carriers cruise through the bloodstream like morning commuters knowing precisely where they are headed; spermatozoa race toward ova, and pollen tubes eagerly extend toward ovules. The obvious implication is that all these hierarchical levels of biological organization involve subordinate elements of biological systems knowing exactly what they are doingexpressing and fulfilling clear intent. All are on the road to progress. Molecules diffuse through membranes because they "want to" even out concentrations (Douglas Allchin, personal communication).

A problem related to "mutation on demand" is that people often think that, whatever situation an organism faces, it will somehow find a solution (e.g., humans will somehow find a way to evolve to tolerate increasing pollution). You can see manifest dangers in this line of thinking. Not only would there be no imperfect organisms if all species got what they "needed," but no species would ever go extinct.

A simple plea for teachers to employ clearer language is weak advice - it will be welcome, but what will be more effective is recognizing and calling out mistaken references to intentionality in students' answers and even in textbook explanations. We get so caught up thinking of nectar as an intentional reward for dutiful pollinators ferrying pollen from one plant to another (where it is "supposed to go") that we fail to see the situation accurately — not only do we tend not to describe the interaction correctly, but we may not even properly understand the evolutionary and ecological basis of this coevolutionary process, and we may fail to recognize how it arose and how it continues to undergo modification.
Teleological Necessity: Do Organisms Evolve Progressively so as to Fulfill Needs?

Related to the common way of thinking about intentions (desires) of organisms is a presumption that organism $X$ "needs to" or "has to" do Y or Z to survive (as with the letter-writer's example of the dog and bacteria cited above). Just as we speak of how nucleotide bases in DNA "need to" pair up, we say that organisms have to do this or that to fulfill basic biological functions of feeding, immunity, sensation, and so on. In some students' minds, just as Pleistocene mammals evolved thicker fur coats or big teeth and claws because they "needed to," we or our ancestors "had to" evolve big brains, binocular vision, and opposable thumbs. The truth is that organisms do not "need" to defend against pathogens; some coevolve to live with them, and others do not survive. Just as biological systems need not be perfect, they need not persist. We are so eager to speak of harmony in nature (with predators "needed" to regulate prey populations and forest fires "needed" to rejuvenate communities and pave the way for ecological succession) that we fall into the trap of explaining complex systems as if they operated like thinking beings rationally planning their existence. Sadly, such descriptions often follow (in texts and lectures) a caution to avoid teleological or Lamarckian explanations. Long live Lamarck! His discredited ideas are commonly ridiculed in biology class and then unwittingly followed.

Chances are that, if you are reading this paper, you already know this mistaken teleological reasoning well. Part of the problem is that biologists and educators routinely speak in a sort of evolutionary shorthand in which we explain that one thing "led to" another and that taxa are "designed" for X and Y. Teleological issues notwithstanding, this is not a problem if we make clear we are speaking of a "bottom-up" rather than a "top-down," teleological design (Dennett 1995). Experienced students likely understand that we routinely omit steps of evolutionary explanations for brevity, if not clarity. Nonetheless, beginning biology students will not have the background to appreciate these distinctions. We must clearly spell out all steps in a causal, mechanistic chain (Alles 2005). Dawkins (2004) notes that biologists easily slip into shorthand patterns of speech or writing "because it chimes with the way humans naturally think." People frequently say that "everything happens for a reason." This is fine in science so long as we are referring to an initial cause rather than a "final," teleological cause: an effect, in other words.

Proximate vs. Ultimate: Does Teleonomy Aid in Avoiding the Pitfall of Progress?

Regarding causes and telos, it is difficult for students to remember the key difference between proximate and 
ultimate causes (Mayr 1993; Shellberg 2001; Ariew 2003; Mead and Scott 2010b). When asked why many organisms engage in sexual reproduction, students promptly respond that it is to generate genetic variation. While this is surely a valid ultimate (evolutionary) cause, it does not explain why we and other organisms enjoy sex. Likewise, we do not sweat to cool off (technically speaking) but rather do so when the hypothalamus triggers glandular secretions on our skin which enable us to cool off. Birds build nests when environmental cues (such as changes in photoperiod) lead to changes in hormone levels. We cannot presume they build nests to have a place in which to lay, hold, incubate, or protect eggs (untestable hypotheses, unlike the first part of this sentence).

A familiar way to avoid such confusion - and perhaps the best way in evolutionary discussions - is to replace teleological explanations (which are goal-directed) with teleonomical explanations, which sound similar but replace final (ultimate) causes with original (proximate) causes and are thus not end-driven. When $\mathrm{A} \rightarrow \mathrm{B} \rightarrow \mathrm{C}$, we must explain B's occurrence via $\mathrm{A}$ as an initial cause, not by $\mathrm{C}$ as an eventual effect. This important distinction was first highlighted in 1958 by Pittendrigh, yet it has failed to gain sufficient traction in classrooms. Comparison of the mechanistic, cause-and-effect chain of action in non-living (i.e., unevolved) and living systems, such as thermostats and furnaces vs. the hypothalamus and sweat glands, offers an effective way to distinguish teleonomy from teleology.

Past vs. Present: What Is Past is Prologue, or Past as Past?

The preceding sections highlight another prominent casualty of the standard model of evolutionary change as progress: We fail to see that evolution is an ongoing process and tend rather to view evolution as an unrolled scroll, an event that has fully happened and is now complete. In short, we may see evolutionary processes as a thing of the past rather than present and future; we may see evolutionary pattern as a merely historical phenomenon rather than a continuing, unending (except for taxa that go extinct) prospect. It is thus useful to discuss the evolution of humans and other species in terms not only of what has unfolded but what may yet come to pass. There have been numerous fascinating books and documentaries based upon sound evolutionary reasoning_Dougal Dixon's After Man (1981) or New Dinosaurs (1988), and the Discovery Channel series The Future Is Wild (2004) —which speculate on what the future might hold as continents and climates continue to change and new species arise.

As anthropologists are fond of pointing out, our anthropocentric view of $H$. sapiens as the culminating pinnacle of a progressive scheme of evolution is fed by an odd quirk of recent history, namely that since the demise of Neanderthals
30,000 or so years ago, ours is the sole hominin species walking the planet. This has been true for all of our recorded history but was obviously not at all the case for the past several million years, when diverse australopithecines and other hominins lived as contemporaries. Drawing students' attention to this historical peculiarity is an interesting and effective way to engage them in deeper discussions of evolution, particularly of human evolution (Werth 2009). Just as it is tough for us to think non-teleologically, it is difficult indeed for people whose lives are ruled by the clock and calendar to conceive of the vastness of deep time and hence to relate adaptive microevolution to the macroevolutionary origin of new species.

Even better than these science fiction accounts of what may come to be are long-term experiments run by the Michigan State University lab of Richard Lenski on $E$. coli (Barrick et al. 2009; Lenski 2011). These hold great promise in aiding students to understand evolutionary processes and their application to current engineering, bioinformatics, and computational problems. Findings by Lenski and other faculty and students at the BEACON Center for the Study of Evolution in Action shed light on the power, process, and pattern of evolutionary change, as do video and computer games (such as Spore, which shows how a microscopic organism might evolve into a complex creature) and program- or module-based digital organism simulators including Creatures, Evolve, Darwinbots, and Primordial Life.

Which Way Is Up? Doesn't Progress Imply Directionality?

As suggested earlier, our view of progress undoubtedly depends on our perspective. When we view evolution as an intentional process, with organisms "needing" or "trying" to adapt, and with some living things "more highly evolved" than others, our bias shows clearly. Perhaps it is no surprise that people often consider other species (dolphins, for example) as less intelligent because their vocalizations do not reflect the same complexity of symbolic, syntactic language that we possess. On the other hand, we seldom stop to think that on a different scale, with dolphins at the top, they could be said to be (if it made any sense to say it) more highly evolved than we are, given their remarkable abilities, including swimming and leaping, deep diving, and echolocation. Just as the victors get to write the history books, humans write the biology books, and we invariably describe and define a progressive world from our standpoint.

The Advance of Evolutionary Progress: A Straight Line in Behavior, as in Fossil Forms?

If evolution were to reflect an inevitable march of progress, a logical corollary is that modern-day phenomena can be 
explained by yesterday's precursors. This is especially common, and unfortunate, in explanations of human behavior. Evolutionary psychology has rightly attracted attention (Geher et al. 2011) - it is only natural that we are curious about our origins and the evolutionary roots of our behaviorbut an unwelcome spin-off is the excuse that "my Paleolithic ancestors made me do it." We are not trapped forever by ancestral habits. Armed with knowledge, we can choose to eat healthy food, even if our appetites crave the fatty, highcalorie food that would have benefited our ancestors greatly. We can choose to exercise, even if people long ago lived such tough lives that they never had a chance to become couch potatoes. We can use birth control or abstain from sex, even if the drive to procreate is one of the strongest in nature. Evolutionary psychology is a potentially valuable field, but to claim that what worked for our ancestors always works for us today, in a very different social environment, is hogwash (Phelan 2001). Many people unfortunately confuse prognosis with prescription, though there is manifestly a huge difference. When a physician says you have condition $\mathrm{X}$, she is not saying this is necessarily a good thing. Likewise, when evolutionary psychologists claim that men seek to have as many sexual partners as possible (so as to better spread their genes), they are not advocating such behavior.

\section{Progress vs. Chance: What's Random and What Isn't?}

Figuring how directed change can arise from non-directed, chance events is a head-scratcher for many students, especially when they are trying to square it with a progressive view of evolution. Mutations arise at random, but clearly this does not mean that evolutionary change is random. After all, students should recognize that the word "selection" refers, as in human terms, to a chosen option, a beneficial preference (Bardapurkar 2008). Children don't close their eyes when choosing sides for kickball teams; they don't "pick" blindly, and neither does selection (natural or artificial, the big difference obviously being that there is no foresight in nature). Herein lies a huge pitfall of evolutionary education: overcoming the mistaken notion that all evolutionary change comes about by chance. To take a familiar example, nicely outlined by Dawkins (2006), equating evolutionary change with a jumbo jet spontaneously assembling out of a junkyard of parts in a windstorm is a ludicrous and wholly unfair accusation. Do plant and animal breeders randomly pick the organisms they will breed, or do they select specimens with physical and behavioral traits they want to amplify in the next generation? This is indeed a cumulative, step-wise (and hence "progressive") process, as is the construction of a jet airplane, as Darwin carefully explained in using artificial selection to set up his argument for natural selection in Origin of Species (1859), yet it is anything but random. If global temperatures rise or fall, will it be random which species thrive and which suffer hardship? If a population of dogs (not the individual dog of the letter-writer above) is subject to an oncoming ice age, will not those with longer hair enjoy a selective advantage, all other things being equal? Such changes are predictable if we know how the environment will change, but because we cannot, this is not progressive. Some whale ancestors came ashore, and some of their descendants later went back to sea, but neither process involved randomness, nor did they involve progress.

Survival of the Fittest: Doesn't Progress Mean that the Winners Are the Strongest?

Finally, a major evolutionary misconceptions stems from Herbert Spencer's unfortunate phrase "survival of the fittest," which too few people recognize as referring to "fitting" the environment and too many people take to mean the biggest or strongest (and thence to "Social Darwinism"). Allchin's suggested "amplification of the aptest" (2007) is a worthy candidate to replace "survival of the fittest," reflecting the fact that even individuals that are less fit can survive, though their genes will likely not be as well represented in the succeeding generation. Regrettably, stereotypical notions of evolution as competition (with a clear winner and loser) further foster belief in evolution as progress and lead one to wonder how descent with modification can lead to "inferior" species that persist today (Schwenk 2002), hence the perennial query, "If we evolved from chimpanzees, why are they still here?" This "chimp fallacy" is fostered by old-school ladder-like (rather than bushlike) evolutionary diagrams (Mead 2009; Kumala 2010; Meikle and Scott 2010). Just as you and your cousins share descent from a common grandparent, so too species share descent from common ancestors. There is a fundamental difference between lineal and collateral relatives, but even direct lineages need not involve progress.

\section{Tackling Preconceptions Head-On}

Educators, particularly professors at the college level-who have been trained primarily as research scholars, and often only incidentally as teachers - frequently believe that students are limited mainly by an absence of knowledge, which, when presented, will fill their minds and clear up problems (Sinatra et al. 2008). However, research has shown that students need more than deeper understanding; they face multiple roadblocks, including entrenched misconceptions and discomfort, when presented with new 
ideas that challenge a preconceived worldview (Drake 1998; Forrest 2008; Nelson 2008). Instead of merely laying on the facts in a misguided attempt to "cure" students' epistemic shortcomings, teachers must confront and challenge these false impressions head-on. Research on cognitive conflicts (Posner et al. 1982; Strike and Posner 1992) has yielded varied results, but generally shows that students abandon preconceptions when teachers carefully guide them through a process of conceptual restructuring. The preceding sections include numerous talking points for lectures or fodder for class discussion, but students will learn more if these topics are approached with an active rather than passive learning model (Timmerman et al. 2008), forcing students to tackle misconceptions directly and personally (Table 1).

It has been widely suggested (Atran 1998; Kelemen 2004b; Kelemen and Rosset 2009; González Galli and Meinardi 2010) that teleology is a culturally conditioned and hardwired human tendency for a valid evolutionary reason: because it helped our ancestors to survive. Ascribing causes to storms and other natural phenomena (such as seasonal changes in weather patterns) enabled humans to adapt to and, in critical ways, learn to control their environment, which would of course bestow great adaptive significance (though this is itself surely a just so story). Such a universal and deep-seated tendency cannot easily be brushed aside, nor can it be treated with a small patch or simple "Band-Aid" solution. The standard educational strategy for dealing with such a cognitive roadblock involves three steps:

1. First, engage and elicit preconceptions: Find out what students' baseline tendencies are, and, importantly, ensure that students are aware of their natural biases before embarking on a classroom quest for conceptual change. Piaget's "constructivist model" of education holds that students bring their history to the classroom: They do not come as blank slates. Teacher and pupil both benefit when made aware of this history. Forewarned is forearmed.

2. Next, engage in counterexamples: Explain counterexamples, anomalies, or discrepant events. In the case of progress and evolution, these might involve the examples cited above of how amphibians and reptiles benefit from an incompletely divided heart, or the fact that skulls and spines have become simpler rather than progressively more complex. The mental confrontation presented by counterexamples often leads to cognitive dissonance, an uncomfortable stage in which conflicting views are held simultaneously. This in turn affords prime opportunities for "teachable moments." This is the time to talk and work through examples carefully and explicitly (Allchin
2003). Laboratory activities or other sessions wherein students guide themselves through problem-solving exercises often work more effectively than lectures because students are forced to do the mental wrestling on their own turf. However, clear examples and anecdotes from instructors and classmates are always welcome (Goldstein 2008).

3. Finally, encourage and enforce (and continually reinforce) an alternative view: Continue to provide examples and activities that engage students' minds and prod them to think in new ways. Choose language (spoken and written) carefully and pay particular attention to students' speaking and writing, offering gently constructive suggestions for better words and turns of phrase. Engage in Socratic dialectic to "unteach" misconceptions, replacing them with proper alternatives (Zollar 2011).

The following dozen examples provide suggested activities for instructors wishing to confront and dispel numerous myths and misconceptions (Table 1) related to notions of evolutionary progress.

A. "What's Right (and Wrong) With This Picture?" Present an evolutionary "picture" (either an actual illustration or a statement or story, as of a blind cavefish, a saber-toothed cat, a pollen-covered bat feeding on a flower, a bird sitting on a nest, or a cheetah running down a zebra) and ask students to explain, explicitly and carefully, exactly what they "see" and how they think that scenario came to be. Or play "Pass It On": Have each student add the next step in the process. Ask students to provide an explanation in simple terms (leaving nothing out) that will convince others, including children as well as experts. A simple way of doing this is to follow a passage or statement with an array of options (as in a multiple choice question), and ask "Which option is not teleological?" It is important that students not only recognize and understand an alternative view, but also that they be able to articulate this new view.

B. "Which Came First?" To make students think about cause-and-effect chains of interactions and force them to describe such a sequence, show them a brief excerpt or vignette, as from a nature documentary (many are available on the Internet). For example, a recent episode of the Animal Planet television series River Monsters ("Cold Blooded Horror," first aired May 22, 2011) featured the namazu or giant Lake Biwa catfish, Silurus biwaensis, of Japan. Because this reclusive fish is rarely seen except shortly before earthquakes, traditional Japanese legend holds that the wriggling movements of this huge fish cause the earthquakes 
Table 1 Suggested strategies to recognize and address student difficulties in understanding that evolution is not an inevitable march of progress, with codes for activities outlined in the text

\begin{tabular}{|c|c|c|c|}
\hline Symptom & Problem & Possible solution & Suggested activity \\
\hline $\begin{array}{l}\text { Students think newer always } \\
\text { equals better }\end{array}$ & $\begin{array}{l}\text { "Parade of progress" view } \\
\text { of evolutionary history } \\
\text { and evolutionary process }\end{array}$ & $\begin{array}{l}\text { Explain that all living taxa are equally } \\
\text { evolved; some look like "living fossils" } \\
\text { and others appear complex, but all } \\
\text { are equally distant from first ancestor }\end{array}$ & C, D, E, F, G, J \\
\hline $\begin{array}{l}\text { Students see evolution as working } \\
\text { toward a planned goal or purpose }\end{array}$ & $\begin{array}{l}\text { Students retain a } \\
\text { teleological view }\end{array}$ & $\begin{array}{l}\text { Try to get students to think and communicate } \\
\text { in terms of teleonomic (non-goal-driven) } \\
\text { processes and explanations }\end{array}$ & $\mathrm{A}, \mathrm{B}, \mathrm{C}, \mathrm{H}$ \\
\hline $\begin{array}{l}\text { Students see organisms "getting a } \\
\text { little better with each succeeding } \\
\text { generation" }\end{array}$ & $\begin{array}{l}\text { Students retain a } \\
\text { Lamarckian worldview }\end{array}$ & $\begin{array}{l}\text { Make clear that organisms seek to survive } \\
\text { and reproduce, but do not strive to or } \\
\text { need to become perfect }\end{array}$ & $\mathrm{A}, \mathrm{C}, \mathrm{I}, \mathrm{J}, \mathrm{K}$ \\
\hline $\begin{array}{l}\text { Students refer to "higher" } \\
\text { and "lower" life forms }\end{array}$ & $\begin{array}{l}\text { Students retain an } \\
\text { Aristotelian view of the } \\
\text { Great Chain of Being }\end{array}$ & $\begin{array}{l}\text { Explore the theory and practice of systematics } \\
\text { from a cladistic viewpoint, not a classical one } \\
\text { (making clear how these schools of thought differ) }\end{array}$ & $\mathrm{D}, \mathrm{E}, \mathrm{H}$ \\
\hline $\begin{array}{l}\text { Students believe evolution } \\
\text { results in perfection }\end{array}$ & Fallacy of optimal design & $\begin{array}{l}\text { Demonstrate imperfections in humans and } \\
\text { other organisms (e.g., vestigial structures), } \\
\text { explaining how existing features are modified }\end{array}$ & $\mathrm{C}, \mathrm{D}, \mathrm{I}, \mathrm{J}$ \\
\hline $\begin{array}{l}\text { Students confuse function } \\
\text { with purpose }\end{array}$ & $\begin{array}{l}\text { Teleological thinking } \\
\text { and conventions of } \\
\text { communication }\end{array}$ & $\begin{array}{l}\text { Explain, for example, that there are other } \\
\text { ways to pump blood than a heart and } \\
\text { other ways to fly than a wing. }\end{array}$ & $\mathrm{A}, \mathrm{K}$ \\
\hline $\begin{array}{l}\text { Students see humans as culminating } \\
\text { pinnacle or end point of evolution }\end{array}$ & $\begin{array}{l}\text { Cultural and intuitive } \\
\text { (hardwired) views } \\
\text { of teleology and } \\
\text { human superiority }\end{array}$ & $\begin{array}{l}\text { Explain importance of chance events in } \\
\text { evolution (e.g., mass extinctions). What } \\
\text { would happen if we "rolled back the tape"? } \\
\text { Might dolphins be superior to us in some ways? }\end{array}$ & $\mathrm{D}, \mathrm{E}, \mathrm{F}, \mathrm{H}, \mathrm{J}$ \\
\hline Students think all change is adaptive & $\begin{array}{l}\text { Adaptationist program } \\
\text { (Spandrels of San Marco) }\end{array}$ & $\begin{array}{l}\text { Show that many features of organisms are } \\
\text { neutral or non-adaptive; some are historical } \\
\text { artifacts, others involve genetic linkage }\end{array}$ & $\mathrm{D}, \mathrm{E}, \mathrm{G}, \mathrm{J}, \mathrm{K}$ \\
\hline $\begin{array}{l}\text { Students believe all features evolve } \\
\text { at the same progressive rate }\end{array}$ & Fallacy of missing links & $\begin{array}{l}\text { Replace notion of missing links with concept } \\
\text { of mosaic evolution (each species as blend } \\
\text { of old and new). }\end{array}$ & $\mathrm{E}, \mathrm{F}, \mathrm{G}, \mathrm{I}$ \\
\hline $\begin{array}{l}\text { Students think evolution works to } \\
\text { fulfill the needs and desires of } \\
\text { organisms }\end{array}$ & $\begin{array}{l}\text { Fallacy of mutation } \\
\text { on demand }\end{array}$ & $\begin{array}{l}\text { Make clear the random vs. non-random } \\
\text { (directed) elements of processes of variation, } \\
\text { selection, and inheritance }\end{array}$ & $\mathrm{A}, \mathrm{C}, \mathrm{K}$ \\
\hline $\begin{array}{l}\text { Students confuse proximate } \\
\text { and ultimate causes }\end{array}$ & $\begin{array}{l}\text { Confusion of teleonomy } \\
\text { and teleology }\end{array}$ & $\begin{array}{l}\text { Have students carefully work out precise } \\
\text { chain of causal mechanisms, as of } \\
\text { hormonal and neural controls of behavior }\end{array}$ & $\mathrm{B}, \mathrm{C}, \mathrm{I}, \mathrm{K}$ \\
\hline $\begin{array}{l}\text { Class discussions generate more } \\
\text { heat than light; students are } \\
\text { uncomfortable "airing out" } \\
\text { views in classroom setting }\end{array}$ & $\begin{array}{l}\text { Discussions of progress } \\
\text { (or lack thereof) unsettling } \\
\text { and "hit close to home" }\end{array}$ & $\begin{array}{l}\text { Writing assignments (essays, reading journals) } \\
\text { offer non-threatening, non-confrontational means } \\
\text { to contemplate and discuss difficult ideas }\end{array}$ & $\begin{array}{l}\text { All activities, } \\
\text { especially L }\end{array}$ \\
\hline
\end{tabular}

to occur. The TV show documented the highly sensitive barbels and other sensory systems of the namazu, suggesting that instead of causing the quakes, it was merely sensing seismic tremors before people became aware of them. In other words, the fish's rare and sudden appearance near the surface of the lake was an effect rather than a cause of the quake. 
C. "Less Talking, More Doing" Following the old Hollywood dictum "Don't say what you can show," cut the expository lecture and instead have students do a simulation to learn the algorithmic, step-wise nature of natural selection (Young and Young 2003; Smith 2010). Numerous free shareware simulations are readily available and easy to find online; these involve generation of variation and presentation of different evolutionary outcomes (according to different parameters of mutation, selection, etc.) by computer. An alternative is to conduct hands-on simulations that involve students throwing dice or using a spinner to create random results in organisms and environments. Cannus stannous, a simulation involving tin cans insulated against heat and cold (provenance unknown; learned about from Dr. Douglas Allchin via Dr. Bill George of Georgetown Day School), involves pretend organisms adapting to local conditions, including other organisms, to dispel notions of progressive evolutionary advancement.

D. "Perfect Imperfection?" Have students try to come up with as many organismal imperfections (in humans and other species) as they can name. These might include but are not necessarily limited to vestigial structures. Why do we get hiccups and "goose bumps" (Shubin 2008)? Ask students to explain imperfect features. Might they be due to historical holdover, genetic linkage, or developmental mechanisms (e.g., canalization)? Discuss scientific and philosophical differences between preordained and stochastic, contingent events, and their implications for evolution. Ask students to explain the key differences between ontogenetic development during the lifespan of a single entity (along an expected path) vs. phylogenetic evolution of a lineage over multiple generations. Note that if evolutionary change truly were progressive, life could be said to develop instead of evolving (Werth 2005; Chorost 2012).

E. Fun with Fossils: Examine the diversity of dinosaurs or other extinct taxa, including pterosaurs and marine reptiles, and distinguish forms that occur earlier in the fossil record with those that appear later. What trends can be noted? Are the more recent forms consistently larger and more complex, and if so in what ways? Why did some complex forms go extinct long before "simpler" dinosaurs appeared? Why do crocodilians look so primitive today, when ancient crocodiles displayed "derived" forms (some giant, others slim, erect, and fastrunning)? In general, ask students to consider in what ways the fossil record does and does not support the concept of evolution as a straight line of increasing progress or complexity.
F. Fun with Living Fossils: Examine "living fossils" of plants and animals that persist despite changing little in appearance from forms that appeared hundreds of millions of years ago in the fossil record. These include many invertebrate (horseshoe crab, chambered nautilus) and vertebrate animals (lamprey, coelacanth, echidna) and plants (ginkgo, cycad, whisk fern). Why are these taxa still around, and why have they not changed morphologically? In fact, aren't many basic forms (jellyfish, earthworms, bacteria) in a sense "living fossils"? What does this tell us about whether evolution is progressive?

G. Protein Evolution: Ask students to consider how the molecular clock demonstrates a relatively constant rate of nucleotide base changes, in coding as well as junk DNA sequences. If biological molecules and similar levels of biological organization are subject to the same forces of evolution as whole organisms (leaving aside the contentious issue of levels of selection), why have some conservative molecules that arose early in evolution not gotten progressively "better" or more complex? Why do all life forms share the same kinds of nucleic acids, along with cytochromes and other basic, membrane-bound metabolic enzymes? Have genomes gotten larger or more complex in "higher" organisms? How can organisms appear to get more complex on the outside without a corresponding increase in "progress" on the inside?

H. Alien Evolution: Think about the extraterrestrial aliens commonly depicted in science fiction movies, television shows, and books. Why are they almost always presented as large-brained, bipedal humanoids like us? Given new capabilities of computer-generated imagery, such aliens no longer need rely on human actors in rubber suits and makeup. What does this tell us about our preconceptions of what intelligent life "should" look like? If we are to find life on Mars or elsewhere, how will it most likely appear? This is another way or "rolling the tape," à la Gould's Wonderful Life thought experiment (1989).

I. Faunal Interchanges and Invasive Alien Species: Consider biogeographic distributions, as of flightless birds on different continents, or of marsupial mammals. Why are they found where they are? What does this tell us about which species are "better" or "worse" or "more" or "less" evolved? What happened during the Great Faunal Interchange (Webb 1976) when North and South America finally became connected during the Pliocene Epoch? Significantly, what happened before this interchange? If some species were inferior (rather than new and improved), why did they not evolve or get outcompeted earlier? Why did 
marsupials diversify in and "take over" Australia if placental mammals are a newer and better link on the evolutionary chain of progress? What happens today when an invasive species (kudzu, zebra mussels, snakehead fish) ends up in a new habitat? What does this tell us about the native species that preexisted in this habitat-were they inferior? If so, why did they not improve?

J. Emphasize Connections: Relate Evolution to Ecology: Students have no trouble understanding or accepting the message that no life exists in isolation: Because all life is connected, all living things evolve together. A focus on coevolution helps drive this point home. Darwin can be seen as the founder of ecology, for he saw that populations change over generations as a result of underlying inherited change, which in turn results in large part from organisms interacting with each other and their environment. Long before "ecology" existed, Darwin recognized the importance of niches, character displacement, and resource partitioning in avoiding competition. At the same time, he understood that the pattern and process of evolution links all species together, not merely in a systematic tree of life joined by common ancestry, but as players in living ecosystems (like actors on a stage). To reinforce the message that humans did not evolve as a "higher" species once other organisms were done evolving, make clear that humans continue to evolve in conjunction with bacteria, lice, and other species. Present ideas and findings in evolutionary medicine; show that parasites and diseases continue to evolve with us (Ewald 1994).

K. Relate Notions of Progress to the Nature of Science: Once again, as educators we must at the very least choose words carefully (Kugler 2002; Thompson 2008). It is possible that the future has already been written, like the three fates of Greek mythology who measure and snip each thread of life at its start. And yet, like the equally possible hypothesis that the sky is blue because it is God's favorite color, this is not a testable, falsifiable proposition, and so it has no place in science. People tend to think non-scientifically (especially teleologically; Kelemen 2004b), which though understandable is not acceptable in the science classroom. Our first and most important task as science educators is explaining what does and does not constitute science. We cannot take this for granted. Exercises or demonstrations on the nature of science (Nickels et al. 1996; Rutledge and Warden 2000; Farber 2003; Lombrozo et al. 2008), including gadgets or "black box" set-ups with mechanical mysteries that students must figure out, go a long way toward showing cause-and-effect relationships and the roles of purpose and design in organismal complexity (Mead and Scott 2010a, b). The ENSI website is a lush source of ideas, as are the Understanding Evolution and Understanding Science websites run by the University of California (Berkeley) Museum of Paleontology.

Also, rather than teaching many lines of evidence for evolution (as presented in many biology texts), ask students instead what could constitute evidence contrary to evolution. What empirical evidence exists, or might exist, that might cause scientists to rethink their support for evolution? It is easy to find multiple lines of consilient evidence supporting evolution. Social and religious objections notwithstanding, no legitimate evidence contradicts the factual nature of evolution.

L. In Confronting the Bugbear of Progress, Stress that Science Does Not Directly Oppose Religion: Sadly, there remains in the minds of many students confusion about whether evolution is merely one of many equally valid views or if it is scientific "truth." Education for most students comes at a time when still impressionable but maturing minds begin to confront competing ideas more openly and objectively. Students should evaluate claims by assessing evidence and judging the motives of those who offer competing claims. They should look for appeals to reason rather than emotion. We would all do well to follow the dictum of Hume (1748), who asserted that the "wise man proportions his belief to the evidence." Warning stickers placed on biology texts admonishing students to "keep an open mind" therefore present a valuable, teachable moment.

Most of all, teachers of science must be careful to adopt a conciliatory tone and not attack deeply seated beliefs which fall outside the purview of science (Meadows et al. 2000; Lovely and Kondrick 2008; Scott and Branch 2009). Notions of progress are linked in many students' minds with deeply cherished worldviews. As Darwin wrote in Descent of Man (1871), "A belief in all-pervading spiritual agencies seems to be universal." Added E.O. Wilson in Consilience (1998): "The human mind evolved to believe in the gods. It did not evolve to believe in biology." The evolution vs. religion battle as commonly presented is a false dichotomy, but regardless of whether one accepts the oft-repeated claim that it is possible for evolutionary thinkers to be deists (Gould 1999; Ruse 2000a; Collins 2006; Miller 2007) or thinks such reconciliation and accommodation is impossible (Coyne 2009), we must recognize that scientific findings are often counterintuitive and thus difficult to comprehend without concerted effort and perhaps a fundamental change in worldview 
(Meadows et al. 2000; Dawkins 2006; Wolpert 2006; Richards 2008). On the topic of progress and directionality in evolution, as with any discussion in science, it is always reasonable to ask students to examine their basic scientific comprehension without undermining or even poking into their personal beliefs.

\section{Conclusions}

Twenty years of teaching have taught me that some students who acknowledge the factual nature of evolution hold misconceptions from what they have heard, read, or been mistaught (McComas 1997). Teachers must begin with the basics, explaining that individual organisms do not evolve and outlining the steps by which populations do evolve. They should explain, for example, that the Second Law of Thermodynamics does not apply to open systems (like Earth), that it is possible to gain objective, empirical evidence about past events (Cooper 2002, 2004), and that punctuated equiibria and gradual evolutionary change can both occur - it is not a contradictory, "either-or" dichotomy. I am sure each educator could add myths and misconceptions to the list presented here. I recommend Ernst Mayr's What Evolution Is (2001) as a superb resource for students and instructors alike. Table 1 lists strategies proven to be successful (Werth 2009) in changing student attitudes and effecting real change in the classroom.

Proper teaching often means "unteaching" a lot of misinformation. The best teachers recognize roadblocks faced by students. We cannot eliminate all such hurdles, but we can help guide students over and around them by teaching clearly and explicitly. Yes, the easiest way to avoid the pitfall of progress - or indeed any trap - is not to fall into it in the first place, but that is an unrealistic expectation considering our ingrained predisposition for teleological thinking. We can't help recognizing order and thinking about purpose and causality (Carroll 2001; Zeigler 2008). We tend to see ourselves as an endpoint of creation and often view other organisms as imperfect creatures that have not ascended to our pinnacle. Finally, we tend to see any change as an improvement and, in the natural world as in the consumer market, any adjustment as a progressive, sensible change. The theme of progress and teleological thinking pops up in many places, and it helps to stamp out or pour water upon as many of these fires as you can find. By stepping carefully and tackling students' misconceptions and apprehensions, we can, like Middlemarch's Arthur Brooke, brag about sure and steady progress - if not as evolving organisms, then at least as effective educators. The strategies presented in this paper offer tried-and-true solutions for climbing out of, and then navigating around, the very deep, very dark, but not inescapable pitfall of progress.

\section{References}

Allchin D. Scientific myth-conceptions. Sci Educ. 2003;87:329-51.

Allchin D. A more fitting analogy: how does one aptly characterize natural selection? Am Biol Teach. 2007;69(3):174-6.

Allcock J. The Triumph of Sociobiology. New York: Oxford; 2001.

Alles D. The nature of evolution. Am Biol Teach. 2005;67(1):7-10.

Animal Planet. Cold blooded horror. River Monsters. 2011.

Ariew A. Ernst Mayr's "ultimate/proximate" distinction reconsidered and reconstructed. Biol Philos. 2003;18(4):553-65.

Atran S. Folk biology and the anthropology of science: cognitive universals and cultural particulars. Behav Brain Sci. 1998;21:54769.

Ayala F. Teleological explanations in evolutionary biology. Philos Sci. 1970;37:1-15.

Barash D. Male response to apparent female adultery in the mountain bluebird: an evolutionary interpretation. Am Nat. 1976;110:1097101.

Bardapurkar A. Do students see the "selection" in organic evolution? A critical review of the causal structure of student explanations. Evol Educ Outreach. 2008;1:299-305.

Barrick J, Yu D, Yoon S, Jeong H, Oh T, Schneider D, Lenski R, Kim $\mathrm{J}$. Genome evolution and adaptation in a long-term experiment with Escherichia coli. Nature. 2009;461:1243-7.

Bartov $\mathrm{H}$. Teaching students to understand the advantages and disadvantages of teleological and anthropomorphic statements in biology. J Res Sci Teach. 1978;15:79-86.

Blitz D. Emergent evolution: qualitative novelty and the levels of reality. Dordrecht: Kluwer; 1992.

Bradbury R. A sound of thunder. New York: Collier's; 1952.

Buschbeck E, Friedrich M. Evolution of insect eyes: tales of ancient heritage, deconstruction, reconstruction, remodeling, and recycling. Evol Educ Outreach. 2008;1(4):448-62.

Carroll S. Chance and necessity: the evolution of morphological complexity and diversity. Nature. 2001;409:1102-9.

Carroll S. Endless forms most beautiful: the new science of evo devo and the making of the Animal kingdom. New York: Norton; 2006.

Chaisson E. Energy rate density as a complexity metric and evolutionary driver. Complexity. 2011;16(3):27-40.

Chorost M. One-way evolution. The ladder of life makes a comeback. New Sci. 2012;2848:35-7.

Collins F. The language of God: a scientist presents evidence for belief. New York: Free Press; 2006.

Conway Morris S. Life's solution: inevitable humans in a lonely universe. Cambridge: Cambridge University Press; 2003.

Cooper R. Scientific knowledge of the past is possible. Am Biol Teach. 2002;64(6):427-32.

Cooper R. How evolutionary biologists reconstruct history: patterns and processes. Am Biol Teach. 2004;66(2):101-8.

Coyne J. Seeing and believing: the never-ending attempt to reconcile science and religion, and why it is doomed to fail. The New Republic online, post date Wednesday, February 4, 2009.

Darwin C. On the origin of species. London: John Murray; 1859.

Darwin C. The descent of man. London: John Murray; 1871.

Dawkins R. God's utility function. Sci Am. 1995;273(6):80-5.

Dawkins R. Climbing Mount Improbable. New York: Norton; 1996.

Dawkins R. Human chauvinism and evolutionary progress. In: Dawkins R, editor. A devil's chaplain. New York: Houghton Mifflin; 2003. p. 206-17.

Dawkins R. The ancestor's tale. New York: Houghton Mifflin; 2004. 
Dawkins R. The God delusion. New York: Houghton Mifflin; 2006.

Dennett D. Darwin's dangerous idea: evolution and the meanings of life. New York: Simon \& Schuster; 1995.

Desmond A. Huxley: from devil's disciple to evolution's high priest. New York: Basic Books; 1997.

Desmond A, Moore J. Darwin: the life of a tormented evolutionist. New York: Norton; 1994.

Discovery Channel. The future is wild. 2004.

Dixon D. After man: a zoology of the future. New York: St. Martin's; 1981.

Dixon D. The new dinosaurs: an alternative evolution. Topsfield: Salem House; 1988.

Drake S. Creating integrated curriculum: proven ways to increase student learning. Thousand Oaks: Corwin; 1998.

Eliot G. Middlemarch. London: John Blackwood; 1871.

Ewald P. Evolution of infectious disease. New York: Oxford; 1994.

Farber P. Teaching evolution \& the nature of science. Am Biol Teach. 2003;65(5):347-54.

Forrest B. Still creationism after all these years: understanding and counteracting intelligent design. Integr Comp Biol. 2008;48 (2):189-201.

Geher G, Crosier B, Dillon H, Chang R. Evolutionary psychology's place in evolutionary studies: a tale of promise and challenge. Evol Educ Outreach. 2011;4:11-6.

Goldstein A. Evolution by example. Evol Educ Outreach. 2008;1:16571.

González Galli L, Meinardi E. The role of teleological thinking in learning the Darwinian model of evolution. Evol Educ Outreach. 2010;4(1):145-52.

Gould S. Sociobiology: the art of storytelling. New Sci. 1978;80:5303.

Gould S. The panda's thumb: more reflections in natural history. New York: Norton; 1980.

Gould S. Of kiwi eggs and the Liberty Bell. Nat Hist. 1986;95(11):20-9.

Gould S. Wonderful life: the burgess shale and the nature of history. New York: Norton; 1989.

Gould S. Rocks of ages: science and religion in the fullness of life. New York: Ballantine; 1999.

Gould S. The structure of evolutionary theory. Cambridge: Belknap/ Harvard; 2002.

Gould S, Lewontin R. The spandrels of San Marco and the Panglossian paradigm: a critique of the adaptationist programme. Proc R Soc Lond B. 1979;205(1161):581-98.

Gregory T. Evolutionary trends. Evol Educ Outreach. 2008a;1:259-73.

Gregory T. The evolution of complex organs. Evol Educ Outreach. 2008b;1(4):358-89.

Gregory T. The argument from design: a guided tour of William Paley's Natural Theology (1802). Evol Educ Outreach. 2009a;2:602-11.

Gregory T. Understanding natural selection: essential concepts and common misconceptions. Evol Educ Outreach. 2009b;2:156-75.

Hill R, Wyse G, Anderson M. Animal physiology. 2nd ed. Sunderland: Sinauer; 2008.

Hume D. An enquiry concerning human understanding. Oxford: Clarendon; 1748.

Jirtle R, Skinner M. Environmental epigenomics and disease susceptibility. Nat Rev Genet. 2007;8(4):253-62.

Jungwirth E. The problem of teleology in biology as a problem of biology-teacher education. J Biol Educ. 1975;9(6):243-6.

Kardong K. Vertebrates: comparative anatomy, function, evolution. 5th ed. New York: McGraw Hill; 2008.

Kelemen D. The scope of teleological thinking in preschool thinking. Cognition. 1999; 70:241-72.

Kelemen D. British and American children's preferences for teleofunctional explanations of the natural world. Cognition. $2003 ; 88: 201-21$.
Kelemen D. Are children “intuitive theists”? Psychol Sci. 2004a;27:295301.

Kelemen D. Counterintuition, existential anxiety, and religion as a byproduct of the designing mind. Behav Brain Sci. 2004b;27:739 40.

Kelemen D, Rosset E. The human function compunction: teleological explanation in adults. Cognition. 2009;111:138-43.

Kelly K. What technology wants. New York: Viking; 2010.

Kingsolver J, Koehl M. Aerodynamics, thermoregulation, and the evolution of insect wings: differential scaling and evolutionary change. Evolution. 1985;39:488-504.

Kipling R. Just so stories for little children. London: Macmillan; 1902.

Kirschner M, Gerhart J. The plausibility of life: resolving Darwin's dilemma. New Haven: Yale; 2005.

Kugler C. Darwin's theory, Mendel's laws: labels \& the teaching of science. Am Biol Teach. 2002;64(5):341-51.

Kumala M. A natural history of you. Evol Educ Outreach. 2010;3:532-8.

Lennox J. Darwin was a teleologist. Biol Philos. 1993;8:409-21.

Lenski R. Evolution in action: a 50,000 generation salute to Charles Darwin. Microbe. 2011;6:30-3.

Lieberman D. The evolution of the human head. Cambridge: Belknap (Harvard); 2011.

Lombrozo T, Thanukos A, Weisberg M. The importance of understanding the nature of science for accepting evolution. Evol Educ Outreach. 2008;1:290-8.

Lovely E, Kondrick L. Teaching evolution: challenging religious preconceptions. Integr Comp Biol. 2008;48(2):164-74.

Mayr E. Proximate and ultimate causations. Biol Philos. 1993;8(1):934.

Mayr E. What evolution is. New York: Basic Books; 2001.

McComas W. The discovery and nature of evolution by natural selection: misconceptions and lessons from the history of science. Am Biol Teach. 1997;59(8):492-500.

McLennan D. The concept of co-option: why evolution often looks miraculous. Evol Educ Outreach. 2008;1:247-58.

McShea D. Complexity and evolution: what everybody knows. Biol 7 Phil. 1991;6:303-24.

McShea D. Evolutionary change in the morphological complexity of the mammalian vertebral column. Evolution. 1993;47(3):730-40.

McShea D. Perspective: metazoan complexity and evolution: is there a trend? Evolution. 1996;50(2):477-92.

McShea D. The minor transitions in hierarchical evolution and the question of a directional bias. J Evol Biol. 2001;14:502-18.

McShea D, Brandon R. Biology's first law: the tendency for diversity and complexity to increase in evolutionary systems. Chicago: Chicago; 2010.

Mead L. Transforming our thinking about transitional forms. Evol Educ Outreach. 2009;2:310-4.

Mead L, Scott E. Problem concepts in evolution part I: purpose and design. Evol Educ Outreach. 2010a;3:78-81.

Mead L, Scott E. Problem concepts in evolution part II: cause and chance. Evol Educ Outreach. 2010b;3:261-4.

Meadows L, Doster E, Jackson D. Managing the conflict between evolution and religion. Am Biol Teach. 2000;62(2):102-7.

Meikle W, Scott E. Why are there still monkeys? Evol Educ Outreach. 2010;3:573-5.

Miller K. Finding Darwin's God: a scientist's search for common ground between God and evolution. New York: Harper; 2007.

Nelson C. Teaching evolution (and all of biology) more effectively: strategies for engagement, critical reasoning, and confronting misconceptions. Integr Comp Biol. 2008;48(2):213-25.

Nickels M, Nelson C, Beard J. Better biology teaching by emphasizing evolution \& the nature of science. Am Biol Teach. 1996;58(6):332-6.

Petto A, Mead L. Misconceptions about the evolution of complexity. Evol Educ Outreach. 2008;1:505-8. 
Phelan J. Mean genes: from sex to money to food: taming our primal instincts. New York: Penguin; 2001.

Popielarz R. 2003. Bacteria adapt, not evolve. Letter to Richmond (Virginia) Times-Dispatch, November 14, 2003: A18.

Posner G, Strike K, Hewson P, Gertzog W. Accommodation of a scientific conception: toward a theory of conceptual change. Sci Educ. 1982;66:211-27.

Quammen D. The reluctant Mr. Darwin: an intimate portrait of Charles Darwin and the making of his theory of evolution. New York: Norton; 2006.

Raven R, Johnson G, Mason K, Losos J. Biology. 8th ed. New York: McGraw-Hill; 2007.

Relethford J. The human species: an introduction to biological anthropology (6e). New York: McGraw Hill; 2005.

Richards R. Philosophical challenges in teaching evolution. Evol Educ Outreach. 2008;1:158-64.

Rubi J. The long arm of the second law. Sci Am. 2008;299:62-7.

Ruse M. Monad to man: the concept of progress in evolutionary biology. Cambridge: Harvard; 1997.

Ruse M. Can a Darwinian be a Christian? Cambridge: Cambridge; 2000a.

Ruse M. Teleology: yesterday, today, and tomorrow? Stud Hist Phil Biol Biomed Sci. 2000b;31:213-32.

Rutledge M, Warden M. Evolutionary theory, the nature of science \& high school biology teachers: critical relationships. Am Biol Teach. 2000;62(1):23-31.

Schlinger H. How the human got its spots: a critical analysis of the just so stories of evolutionary psychology. Skeptic. 1996;4:68-76.

Schwenk K. Aristotle's ghost. Creat Nonfiction. 2002;19:32-40.

Scott E, Branch G. Don't call it "Darwinism". Evol Educ Outreach. 2009;2:90-4.

Shanks N, Green K. Intelligent design in theological perspective. Synthese. 2011;178:307-30.

Shellberg T. Teaching how to answer 'why' questions about biology. Am Biol Teach. 2001;63(1):16-9.

Shermer M. Why Darwin matters. New York: Henry Holt; 2006.

Shubin N. Your inner fish: a journey into the 3.5-billion-year history of the human body. New York: Pantheon; 2008.

Sinatra G, Brem S, Evans E. Changing minds? Implications of conceptual change for teaching and learning about biological evolution. Evol Educ Outreach. 2008;1:189-95.

Smart J. Evo devo universe? A framework for speculations on cosmic culture. In: Om Dick S, Lupisella M, editors. Cosmos and culture: cultural evolution in a cosmic context. Washington, DC: NASA SP-2009-4802; 2009. p. 201-95.

Smith C. A three-step method for teaching the principles of evolution to non-biology major undergraduates. Evol Edu Outreach. 2010;4 (2):293-7.

Strike K, Posner G. A revisionist theory of conceptual change. In: Duschl R, Hamilton R, editors. Philosophy of science, cognitive psychology, and educational theory and practice. Albany: SUNY; 1992. p. 147-76.

Thompson J. Use the word evolution. Evol Educ Outreach. 2008;1:42-3.

Timmerman B, Strickland D, Carstenson S. Curricular reform and inquiry teaching in biology: where are our efforts most fruitfully invested? Integr Comp Biol. 2008;48(2):226-40.

Trut L. Early canid domestication: the farm-fox experiment. Am Sci. 1999;87(2):160-9.

Van Valen L. A new evolutionary law. Evol Theory. 1973;1:1-30.

Wagner A. Robustness and evolvability in living systems. Princeton: Princeton; 2007.

Webb S. Mammalian faunal dynamics and the great American interchange. Paleobiology. 1976;2:220-34.

Weber B. Design and its discontents. Synthese. 2011;178:271-89.

Werth A. Evolution and development are not the same (Letter to the Editor). Am Biol Teach. 2005;67(4):201-2.

Werth A. Clearing the highest hurdle: human-based case studies broaden students' knowledge of core evolutionary concepts. J Eff Teach. 2009;9(2):38-53.

Williams G. The pony fish's glow and other clues to plan and purpose in nature. New York: Basic; 1998.

Wilson E. Consilience: the unity of knowledge. New York: Knopf; 1998.

Wolpert L. Six impossible things before breakfast: the evolutionary origins of belief. New York: Norton; 2006.

Wright R. Nonzero: the logic of human destiny. New York: Vintage; 2001.

Young H, Young T. A hands-on exercise to demonstrate evolution by natural selection \& genetic drift. Am Biol Teach. 2003;65(6):444-8.

Zeigler D. The question of purpose. Evol Educ Outreach. 2008;1:44-5.

Zohar A, Ginossar S. Lifting the taboo regarding teleology and anthropomorphism in biology education-heretical suggestions. Sci Educ. 1998;82:679-97.

Zollar U. Students' misunderstandings and misconceptions in college freshman chemistry (general and organic). J Res Sci Teach. 2011;27:1053-65. 